\title{
FONTES CENSITÁRIAS BRASILEIRAS E POSSE DE CATIVOS NA DÉCADA DE 1870
}

POR

\author{
RENATO LEITE MARCONDES*
}

Universidade de São Paulo

Existe um conjunto expressivo de fontes de caráter censitário para o estudo da escravidão da década de 1870. Estas fontes derivam, principalmente, da matricula dos escravos determinada pela Lei do Ventre Livre de 1871. Neste artigo discutimos as diferentes formas de apresentação das informações da matrícula. Analisamos uma amostra da população escrava matriculada, compreendendo 69 localidades de diferentes partes do país que totalizam pouco mais de 112 mil escravos e 25 mil escravistas. Além caracterizar o perfil demográfico dos escravos da amostra, verificamos a posse de cativos.

Palavras chave: Matrícula, escravidão, demografia, posse cativa, Lei do Ventre Livre.

Dos engenhos, uns se chamam reais, outros, inferiores, vulgarmente engenhocas. Os reais ganharam este apelido por terem todas as partes de que se compõem e de todas as oficinas, perfeitas, cheias de grande número de escravos, com muitos canaviais próprios e outros obrigados à moenda; e principalmente por terem a realeza de moerem com água, à diferença de outros, que moem com cavalos e bois e são menos providos e aparelhados; ou, pelo menos, com menor perfeição e largueza, das oficinas necessárias e com pouco número de escravos, para fazerem, como dizem, o engenho moente e corrente.

Antonil - João Antônio Andreoni

* Professor da Faculdade de Economia, Administração e Contabilidade de Ribeirão Preto (FEA-RP/USP). É membro do Núcleo de Estudos Comparados do Escravismo Brasileiro NUCESC. O autor agradece ao apoio da FAP-DF, do CNPq e da Fapesp. Este estudo faz parte de uma pesquisa mais ampla publicada em livro (Marcondes, 2009). 
Nas últimas décadas um conjunto relativamente expressivo de novas evidências empíricas procurou qualificar as afirmativas clássicas acerca da grande lavoura escravista. De acordo com essas obras ${ }^{1}$, uma característica essencial da sociedade escravista brasileira foi a grande exploração agrícola, utilizando em larga escala mão-de-obra cativa. Nas últimas décadas, novos estudos monográficos ${ }^{2}$, apontaram, para diferentes partes do país e especialmente para a segunda metade do século XVIII e a primeira metade do XIX, resultados distintos dos vislumbrados pela historiografia pioneira. A partir de fontes primárias inéditas, principalmente arrolamentos nominativos de habitantes, esses autores reavaliaram as posses cativas dos senhores, que, na maioria dos casos, não atingiu mais de cinco cativos, sendo que poucos detinham mais de quarenta cativos ${ }^{3}$. Tais resultados foram a princípio entendidos como específicos das áreas mineradoras ou voltadas ao abastecimento do mercado interno; aos poucos, contudo, consolidou-se a visão bastante abrangente da dominância dos pequenos proprietários entre os escravistas nesse período ${ }^{4}$.

1 Freyre, 1933; Buarque de Holanda, 1936; Prado Júnior, 1942; Furtado, 1959.

2 Luna, 1981; Schwartz, 1988; Costa \& Nozoe, 1989; Motta, 1999; Paiva, 1996; Barickman, 2003 e Luna \& Klein, 2004.

3 As listas nominativas de habitantes são levantamentos pré-censitários, anteriores ao primeiro censo do Brasil realizado em 1872/74. Eles aprimoraram levantamentos anteriores, especialmente caráter militar, que eram bastante seletivos no recenseamento da população. A partir da restauração da capitania de São Paulo em 1765, o novo governador reorganizou as forças militares para conter o avanço castelhano. Para facilitar o recrutamento efetuou-se um censo em todos os municípios da capitania, que naquele momento abrangia a região compreendida atualmente não apenas pelo Estado de São Paulo, mas também o do Paraná e interior de Santa Catarina. Eles foram realizados de forma seriada a partir de 1765 e ganharam maior abrangência ao final do século, tornando-se bastante minuciosos não apenas com relação à totalidade da população e de suas movimentações, mas também com informações econômicas de renda e produção agrícola. A partir da Independência, em 1822, houve uma desorganização dos levantamentos, começando a ser realizado de forma mais espaçada e menos minuciosa principalmente após 1830 (ver Marcílio, 1974: 77-94; Nadalin, 2004: 47-53). Paralelamente, outros levantamentos de caráter censitário foram realizados para as outras províncias, como as de Minas Gerais (ver Luna, 1981, Costa, 1992 e Paiva, 1996), Bahia (Schwartz, 1988), Goiás (Funes, 1986) e Piauí (Mott, 1985 e Falci, 1995), especialmente do final do século XVIII até a década de 1830. Além das forças militares e arrecadatórias, a Igreja também realizava, no período colonial, levantamentos de caráter censitário, como os róis de confessados, compreendendo até mesmo a população escrava, como os realizados para o Rio Grande do Sul ao final do século XVIII. Kühn, 2004 e 2006. Por fim, existem levantamentos específicos dos escravos de algumas áreas, como os das vilas mineradoras por meio das listas de capitação dos escravos da primeira metade do século XVIII. Luna, 1981 e Valentin, 2001 e os do Maranhão no meado do século XIX. Marcondes, 2005.

4 Entre os mais de trinta mil escravistas analisados por Luna \& Klein para Minas Gerais, São Paulo e Paraná na década de 1830, apenas pouco mais de quinhentos detinha um número 
Para o momento anterior a 1718 ou posterior a 1840 , são poucas as informações censitárias dos habitantes que poderiam servir para a análise da população cativa ou mesmo da posse de cativos $^{5}$. Períodos de pujança da economia exportadora não poderiam ser contemplados, como o açúcar na primeira metade do século XVII e o café na segunda metade do século XIX. Mesmo o primeiro censo do Império realizado em 1872/74, que poderia possibilitar esse tipo de estudo, também não nos legou os seus micro-dados ${ }^{6}$. Deste modo, a historiografia mais recente procurou se apoiar em outras fontes de caráter censitário para efetuar tal discussão, como as listas e os livros de matrícula especial ou classificação dos escravos para a década de $1870^{7}$.

Nesse artigo, apresentamos esta documentação alternativa e discutimos o perfil da população e a estrutura da posse cativa para um conjunto de diferentes municípios brasileiros selecionados para a pesquisa na década de 1870 . De início, qualificamos a documentação e a amostra que embasou esta pesquisa, especialmente a sua representatividade na totalidade do território nacional e em termos da composição etária. Posteriormente, analisamos as características demográficas e econômicas dos escravos matriculados e/ou classificados nes-

superior a 40 cativos, representando $1,8 \%$ do total. De outro lado, quase um quarto dos escravistas possuíam tão-somente um cativo $(24,5 \%)$. Ademais, cerca de dois terços dos escravistas mantinham de 1 a 5 cativos em seus plantéis $(66,5 \%)$. A concentração das posses mostrou-se notória, pois estes últimos detinham apenas 23,4\% dos escravos (Luna \& Klein, 2004: 10). Por fim, de forma ilustrativa, observamos, no caso de Iguape situada no recôncavo baiano, que quase a metade dos escravistas detinha até quatro escravos em 1835. Barickman, 2003: 241.

5 Não consideramos neste artigo os estudos da posse cativa a partir de inventários post mortem, pois a comparabilidade destes com os resultados da análise baseada em arrolamentos nominativos mostra-se prejudicada. Richard Graham já chamou a atenção para esta questão (1983: 248). Mais recentemente, Maurício Martins apontou, ao estudar Taubaté (SP) de 1680 a 1848 , uma posse média de escravos calculada a partir de listas nominativas superior a dos inventários, bem como a representatividade dos senhores de poucos escravos revelou-se maior nas listas (2001: 17-35). Por fim, Zephyr Frank verificou, para a região do Rio das Mortes em Minas Gerais na década de 1830, «as informações dos inventários se correlacionam bem com as relativas às das listas nominativas. A amostra de inventários rendeu uma média de 8,74 escravos entre os falecidos, contra uma média de 7,42 entre os proprietários recenseados». Frank, 2006: 12 .

${ }^{6}$ Houve um arrolamento populacional prévio ao censo na paróquia de São Cristovão do município da Corte em 1870, para o qual se dispõe dos micro-dados (ver http://biblioteca.ibge.gov.br/visualizacao/monografias/visualiza_colecao_digital.php?titulo=Recenseamento \%201870:\%20S\%E3o\%20Christov\%E3o\&link=Recenseamento_1870_Sao_Cristovao).

7 Segundo Robert W. Slenes, para o período posterior a 1850, os livros de matrícula são os «únicos manuscritos nominativos de um censo nacional (fora, talvez, os dos recenseamentos de hoje em dia) que têm sido preservados, ainda que de forma parcial, por todo o país». Slenes, 1983: 120 . 
sa amostra, realizando uma divisão por regiões. Por fim, analisamos a distribuição da posse de cativos do conjunto destas localidades, mostrando a importância absoluta e relativa dos distintos tamanhos de plantéis dos escravistas. As condições sociais, econômicas e até mesmo geográficas das regiões demarcaram o padrão de propriedade escrava daquela época.

\section{FONTES CENSITÁRIAS PARA A ESCRAVIDÃO}

Podemos considerar a população escrava mais registrada por parte dos administradores coloniais e imperiais do que a própria população livre, especialmente a mais pobre. Tal afirmativa decorre do escravo constituir uma propriedade do senhor, tornando-o passível de compra, venda, herança, alforria, doação, tributação, hipoteca, penhor, aluguel, dote, matrícula etc. Tais operações transformaram-se, na maior parte das vezes, em algum registro documental do escravo, apesar de não efetuado pelo próprio, mas por meio do seu proprietário ou de um terceiro. Na questão das fontes censitárias, podemos ilustrar o registro específico dos escravos por meio de um conjunto documental do período da América portuguesa: as listas nominativas de capitação derivadas da tributação sobre os escravos moradores das áreas mineradoras e efetuadas na primeira metade do século XVIII. Ademais, a documentação censitária pode assumir um caráter específico de uma província em função de algum conflito ou interesse, como as relações e os mapas dos escravos maranhenses posteriores às revoltas do período regencial.

Posteriormente às afamadas listas nominativas de habitantes do final do século XVIII e das primeiras décadas do XIX, realizou-se o primeiro recenseamento do Império em 1872/74, que, porém, não nos legou informações individualizadas das pessoas; ou, pelo menos, ainda não foram descobertos os seus micro-dados, que talvez nunca o sejam. Dispomos apenas das tabelas mais agregadas por paróquia, que nos permitem alguns recortes a respeito da demografia escrava para quase a totalidade das vilas existentes naquele momento ${ }^{8}$. Tais tabelas apresentam as seguintes informações da população paroquial: sexo, cor (preto e pardo), estado conjugal (casado, viúvo e solteiro), faixa etária, religião (todos católicos?), nacionalidade (brasileiro ou não), alfabetização (sabe ler e escrever), deficiências físicas e profissão. Esse detalhamento de informações dos escravos por paróquia nos possibilita analisar diversos recortes, como, por exemplo, a distribuição da população pelo território, a

8 DGE, 1876. 
participação dos escravos na população livre, a construção de pirâmides etárias etc. Apesar disto, não podemos conhecer, por exemplo, as relações familiares além das conjugais entre os cativos paroquianos e a distribuição deles de acordo com o tamanho da propriedade escrava do proprietário. Os recortes de apresentação dos resultados são dados pelas tabelas publicadas na época, não permitindo ao pesquisador alterar a forma de análise das informações.

Uma alternativa a estas restrições pode ser a documentação produzida a partir da aprovação da Lei do Ventre Livre (no 2.040) em 28 de setembro de 1871, que libertou os nascituros nesta data, denominados de ingênuos ${ }^{9}$. Nessa lei, instituiu-se obrigatoriamente a matrícula de todos os escravos:

Art. $8 .^{\circ}$ - O Governo mandará proceder a matrícula especial de todos os escravos existentes no Império, com declaração de nome, sexo, estado, aptidão para o trabalho e filiação de cada um, se for conhecida. [...] § 2. ${ }^{\circ}$ - Os escravos que, por culpa ou omissão dos interessados não forem dados à matrícula, até um ano depois do encerramento desta, serão por este fato considerados libertos ${ }^{10}$.

As matrículas dos escravos representam uma alternativa importante na falta dos recenseamentos, possibilitando - como veremos adiante - o estudo da posse de cativos ${ }^{11}$. Este levantamento assumiu funções censitárias, devendo compreender informações individualizadas de todos os cativos do país. Todo o escravo recebeu um número de matrícula em seu município, que deveria ser mencionado em qualquer processo que envolvesse o cativo como sua identificação. Esta lei ainda criou um fundo de recursos para a libertação dos escra$\operatorname{vos}^{12}$. Tal lei foi regulamentada pelo decreto 4.835 de 1 de dezembro de 1871 , que especificou de melhor modo as informações a serem levantadas e a sequência das informações na matrícula:

Art. 1. A matrícula de todos os escravos existentes conterá as seguintes declarações: $1 .^{\circ} \mathrm{O}$ nome por inteiro e o lugar da residência do senhor do matriculado; $2 .^{\circ} \mathrm{O}$ número de ordem do matriculado na matricula dos escravos do município e nas relações do que trata o art. $2 .^{\circ}$ deste Regulamento; $3 .^{\circ} \mathrm{O}$ nome, sexo, cor, idade,

9 Esta legislação teve influência da Lei Moret da Espanha de 1870, que registrava e libertava os filhos de mães escravas e as pessoas maiores de sessenta anos. A lei espanhola foi utilizada como referência pelos legisladores brasileiros. Slenes, 1983: 132.

$10 \mathrm{http}: / / \mathrm{www}$. soleis.adv.br/leishistoricas.htm.

11 Existiram anteriormente e posteriormente outras tentativas de matrícula dos escravos, como a matrícula geral de 1886-87 após a lei que libertava os sexagenários, porém esta foi a mais abrangente e completa.

12 O Fundo de Emancipação receberia recursos para serem utilizados na libertação dos escravos, conforme o «Art. 3. ${ }^{\circ}$ - Serão anualmente libertados em cada província do Império tantos escravos quantos corresponderem à quota anualmente disponível do fundo destinado para a emancipação». Ventre Livre, 1871. 
estado, filiação (se for conhecida), aptidão para o trabalho e profissão do matriculado; 4. ${ }^{\circ}$ A data da matrícula; 5. Averbações;

Art. 2. ${ }^{\circ} \quad$ A matrícula dos escravos será feita no município em que eles residirem $(\ldots)$

Art. 8. ${ }^{\circ}$ Aos Coletores, Administradores de Mesas de Rendas e de Recebedorias de Rendas Gerais internas, e Inspetores das Alfandegas nos municípios onde não houver aquelas estações fiscais, compete fazer a matrícula ${ }^{13}$.

Adicionaram-se os dados de cor, idade e profissão aos registros de matrícula, não previstos na Lei do Ventre Livre ${ }^{14}$. A matrícula especial deveria ocorrer entre abril de 1872 e setembro de 1873, sob punição de multa e, depois de um ano de atraso em relação ao término da matrícula, os escravos não registrados seriam considerados libertos. Na matrícula, os escravistas receberam ao matricularem seus escravos nos municípios uma cópia da relação dos matriculados, que a partir desse momento deveria ser apresentada pelos herdeiros do escravista como comprovação da propriedade nos inventários ${ }^{15}$. Houve grande adesão a matrícula pelos escravistas, pois se matriculou praticamente toda a população recenseada naquela mesma época (ver Slenes, 1983: 121-124). A partir da matrícula dos cativos pelos proprietários deveria ser efetuado o livro de matrícula do município. Nesse período, regulamentou-se o Fundo de Emancipação em 13 de novembro de 1872 mediante o decreto 5.135. Para a utilização dos recursos na libertação dos escravos estabeleceu-se critérios de prioridade para a compra da liberdade. Este regulamento determinava a classificação dos cativos em duas ordens como segue ${ }^{16}$ :

I. Famílias;

II. Indivíduos;

$\S 1 .^{\circ} \mathrm{Na}$ libertação por famílias, preferirão:

I. Os cônjuges que forem escravos de diferentes senhores;

$13 \mathrm{http} / /$ www.camara.gov.br/internet/infdoc/conteudo/colecoes/legislacao/legimpcd-06/ leis 1871 pdf96.pdf\#page $=7$

14 Ao comparar a qualidade das informações da matrícula com as do censo daquele momento, Robert Slenes verificou que são «bastante confiáveis», sendo na matrícula houve uma tendência de redução das idades dos escravos mais idosos. A possibilidade de libertação dos sexagenários condicionou este procedimento dos proprietários. Slenes, 1983: 132-133.

${ }^{15} \mathrm{Um}$ exemplo de matrícula individual de proprietário consiste na seguinte: «Relação n. ${ }^{\circ} 488$ dos escravos pertencentes a Alberto Moreira Castro residente na cidade de Lençóis província da Bahia município dos Lençóis paróquia de N. S. da Conceição». A partir deste título são relacionados os escravos e o documento é encerrado, sendo nesse caso com a afirmativa: «Apresentado a matrícula e matriculado em 14 de outubro de 1872, pagou um mil réis de emolumentos.»

$16 \mathrm{http}: / /$ www6.senado.gov.br/legislacao/ListaPublicacoes.action?id=76935\&tipoDocumento $=$ DEC\&tipoTexto $=$ PUB 
II. Os cônjuges, que tiverem filhos nascidos livres em virtude da lei e menores de oito anos;

III. Os cônjuges, que tiverem filhos livres menores de vinte e um anos;

IV. Os cônjuges com filhos menores escravos;

V. As mães com, filhos menores escravos;

VI. Os cônjuges sem filhos menores.

$\S 2 .^{\circ} \mathrm{Na}$ libertação por indivíduos, preferirão:

I. A mãe ou pai com filhos livres;

II. Os de doze a cinquenta anos de idade, começando pelos mais moços do sexo feminino, e pelos mais velhos do sexo masculino

A partir da matrícula, a junta de classificação composta pelo presidente da Câmara, Promotor público e coletor distribuiu os cativos nessas ordens e depois registraram no livro de classificação dos escravos para serem libertados pelo Fundo de Emancipação. A classificação deveria ser atualizada periodicamente nesse livro em novas listagens, contemplando as alterações decorrentes do falecimento ou migração dessa população e a própria libertação. Contudo, a reduzida efetividade da libertação pelo fundo em virtude da carência de recursos restringiu a necessidade de revisar a lista de classificação ${ }^{17}$. Além de alterar a sequência dos dados com relação ao de matrícula, a classificação incluiu duas novas variáveis: valor e moralidade do escravo, que deveriam ser considerados na libertação ${ }^{18}$. Apesar de abarcar a grande maioria dos escravos, a classificação não contemplou, ao contrário da matrícula, a totalidade da população escrava do município, pois os menores de 12 anos e maiores de $50 \mathrm{sem}$ vínculos familiares não seriam classificados para a libertação. Tal lacuna mostrou-se mais importante entre os idosos do que entre as crianças, pois estas mantinham maiores relações familiares, especialmente com a mãe e irmãos. Se a matrícula nos fornece o conjunto total dos cativos, as duas outras fontes derivadas da matrícula apresentam amostras incompletas do total de escravos. A partir dos inventários post-morten os pesquisadores procuraram remontar a

17 Um estudo pioneiro com base nas listas de classificação dos escravos para a libertação foi efetuado por Márcia Graf em sua dissertação de Mestrado acerca do Paraná (cf. Graf, 1974). Embora não realize um estudo da estrutura de posse de cativos, ela apresenta detalhadamente as fontes e as características da população escrava. Os seus resultados da exploração dos dados mostraram a ineficácia do Fundo de Emancipação para a libertação gradativa dos escravos e as características demográficas (sexo, idade, ocupação) do segmento cativo estudado. Rui Barbosa já tinha apontado naquele momento de 1884: «a mola redentora pomposamente magnificada sob o título de fundo de emancipação resgatou apenas 20.000 , e a caridade individual cerca de 90.000 cativos. O resultado é ainda essa massa enorme de um Milão e cem mil escravos». Barbosa, 1988: 59.

18 As informações apresentadas das listas e livros de classificação foram as seguintes: número da matrícula, nome, cor, idade, estado, profissão, aptidão para o trabalho, pessoa de família, moralidade, valor, nome do senhor e observação. 
população por meio das relações de escravos pertencentes aos proprietários anexadas a estes processos ${ }^{19}$. Como nem todos os escravistas que matricularam seus escravos em 1872 e 1873 faleceram até 1888, esta abordagem também se mostra bastante parcial em comparação à totalidade da população cativa. Assim, estes dois caminhos de pesquisa baseados nessas fontes permitem a reconstrução de uma parcela da população escrava, remontada por meio do nome dos proprietários, escravos e número de matrícula.

Os livros de matrícula são, atualmente, bastante raros para a maior parte do território brasileiro, à exceção da província de Goiás. As duas outras fontes derivadas da matrícula mostraram-se mais frequentemente utilizadas pelos pesquisadores: relações de escravos dos proprietários e a classificação. O primeiro documento foi obtido em geral nos inventários e permitem remontar os plantéis de forma integral dos seus proprietários. Como nem todos os proprietários da matrícula deixaram inventários ou esses processos não sobreviveram até hoje, há uma lacuna importante, que em geral compreende segundo nossa experiência de dez a vinte pontos porcentuais do total matriculado. Já a classificação compreendeu, em geral, uma maior parcela da população cativa disposta nas várias ordens, porém nem todos os escravos dos proprietários foram classificados como informado acima ${ }^{20}$. Os estudos mais recentes utilizaram-se principalmente as listas ou livros de classificação para a análise da população escrava daquela época ${ }^{21}$.

A escolha para a nossa pesquisa recaiu sobre os três tipos de registros decorrentes da matrícula especial dos escravos: livros de matrícula, relações de escravos pertencentes aos proprietários e a classificação ${ }^{22}$. Por ainda existirem

19 Slenes, 1983 e 1998.

20 A partir dos escravos dispostos nas diversas ordens da classificação, o pesquisador reconstrói os plantéis por meio do nome do proprietário e número de matrícula. Contudo, os menores de 12 anos e maiores de 50 que não possuíam relações familiares não foram classificados.

21 Vários autores debruçaram-se sobre essa documentação para alguns municípios brasileiros, realizando, na maioria das vezes, análise da propriedade escrava: Galliza, 1979; Slenes, 1983; Falci, 1995; Paiva e Libby, 1995; Castro e Schnoor, 1995; Passos Subrinho, 1997 e Pena, 1999. Os estudos da demografia escrava por meio dos inventários não se restringiram, na maior parte dos casos, a documentação da matrícula e seu período, dificultando a comparação com as informações analisadas.

$22 \mathrm{Na}$ maior parte dos casos lançamos mão de listas ou livros de classificação dos escravos para libertação pelo Fundo de Emancipação e nem tanto de livros de matrículas, que foram mais comuns apenas para Goiás. A classificação não retrata toda a população da localidade e em alguns casos não pudemos incorporá-los nesta pesquisa em função do pequeno número de escravos retratados em relação ao total matriculado, em geral quando inferior à metade do total. De outro lado, em certos casos conseguimos utilizar de forma complementar à classificação as relações de matrícula dos proprietários apensadas aos inventários, como no caso de Amparo, 
espalhados pelos arquivos estaduais e municipais, cartórios, bibliotecas e museus debruçamo-nos, principalmente, sobre as listas ou livros de classificação dos escravos para libertação pelo Fundo de Emancipação e, em menor monta, nos de matrícula, efetuados mormente entre 1872 e $1877^{23}$. Essas fontes mostraram-se relativamente homogêneas e existentes para diversas localidades de diferentes províncias brasileiras, possibilitando o estudo da propriedade escrava de distintas áreas. Localizamos essa documentação para quase a totalidade das províncias, porém a cobertura do conjunto dos seus municípios oscilou muito. Em algumas se revelou bastante completa a amostragem - como Goiás, Paraná e Piauí-, contudo em outras se restringiu a tão-somente um município - por exemplo Pará, Maranhão, Espírito Santo e Rio de Janeiro- . $O$ vale do Paraíba fluminense, que constituiu uma das principais áreas cafeeiras do país, não apresentou informes muito abrangentes. De todo modo, uma amostra de 69 localidades para várias províncias garantiu a viabilidade do estudo, compreendendo as mais diversas partes do país, desde a campanha gaúcha até a floresta amazônica paraense sem desconsiderar o litoral, planalto, cerrado, sertão etc.

\section{AMOSTRA E LIMITES}

Os dados levantados apresentam duas ausências bastante notórias, em termos de algumas idades e do espaço brasileiro. A primeira refere-se à própria documentação e ao momento da sua feitura, já posterior a Lei do Ventre Livre e com a ausência da totalidade dos ingênuos. De igual sorte, como salientado antes, a classificação dos escravos para a libertação pelo Fundo de Emancipação não contemplavam indivíduos sem família com idades menores do que 12 anos e maiores de 50 anos. No caso dos mais jovens não classificados, as ausências deveriam ser menores, pois muitas crianças mantinham laços familiares, porém as lacunas revelaram-se maiores para os mais idosos. Podemos avaliar de melhor forma estas ausências no gráfico 1 da pirâmide etária da população escrava de nossa amostragem. Como esperado, houve uma reduzida

Itu, Lagarto, Lorena, Mogi das Cruzes, Ouro Preto, Ponte Nova, Rio Pardo e Dom Pedrito. No apêndice do artigo, apresentamos as fontes utilizadas (livro de matrícula, relação de escravos e classificação) para todas as localidades em consideração nesta pesquisa. Assim, realizamos um esforço de cruzamento das fontes e reconstrução destas populações cativas, controlada pelo nome do proprietário e o nome e número de matrícula dos escravos. Para maiores informações dos procedimentos metodológicos desta pesquisa ver Marcondes, 2009.

23 A maior parte das informações refere-se aos anos de 1872 a 1875. 
proporção de crianças até quatro anos de idade, mas para a faixa etária subseqüente a representatividade cresceu significativamente ${ }^{24}$. De forma semelhante, a redução da proporção de idosos a partir da faixa de 50 a 54 anos e principalmente da de 55 a 59 anos também foi significativa, confirmando a análise anterior de Robert Slenes.

Gráfico 1. PirÂmide Etária dos escravos da Amostra

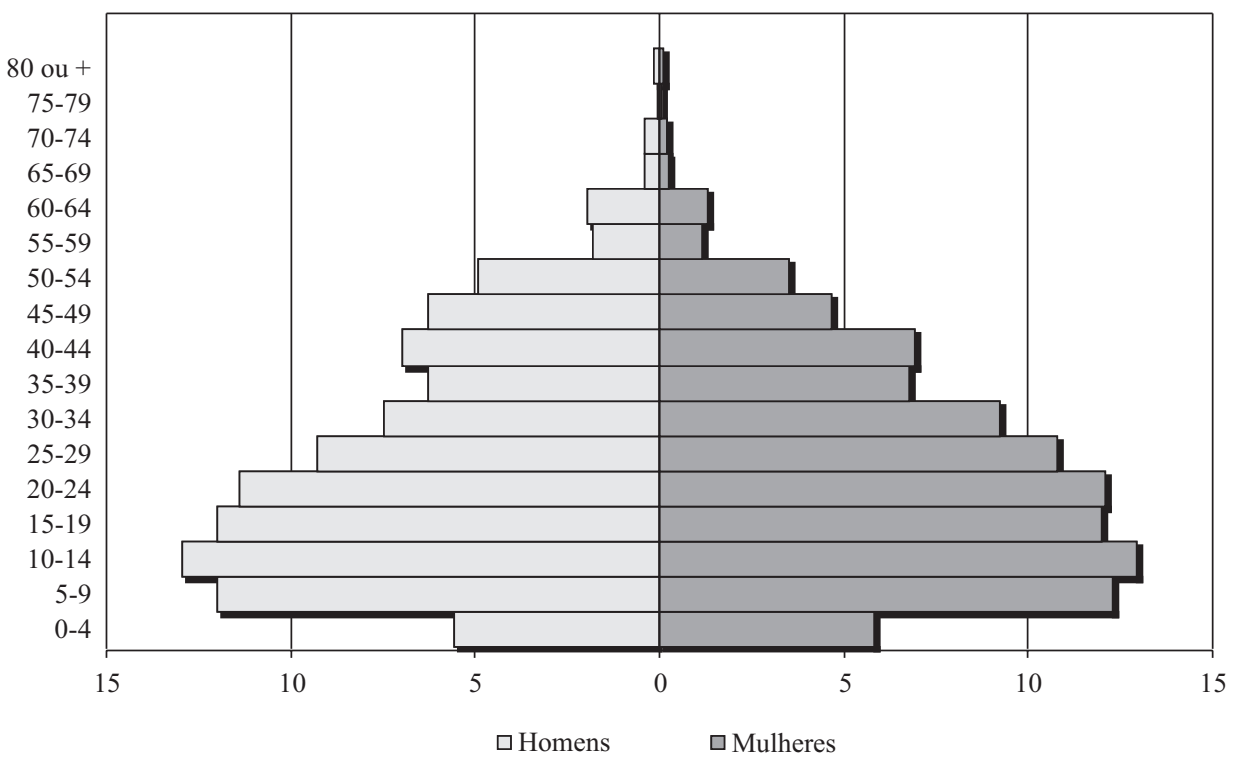

24 Podemos comparar nossos resultados com os dados agregados da matrícula, a fim de verificar mais precisamente estas diferenças. Para tanto, reorganizamos as informações das idades de acordo com a apresentação nessa fonte (ver Oliveira, 1875, anexo G6-SN). Nela, as crianças até um ano representavam $1,2 \%$ e apenas $0,2 \%$ em nossa amostra, salientando a lacuna as crianças mais novas. Na faixa seguinte (de 1 a 7 anos), a matrícula informou a presença de $15,0 \%$ dos escravos e a nossa amostra $10,4 \%$, demonstrando um menor sub-registro. No grupo etário subseqüente, a matrícula forneceu a participação de $16,4 \%$ dos cativos e a nossa amostra 17,6\%. Para os escravos em idade mais ativa (de 15 a 49 anos), eles representavam $59,4 \%$ dos matriculados e $63,6 \%$ dos da amostragem. Por fim, os idosos (de 50 ou mais anos) perfizeram $8,0 \%$ na matrícula e $8,2 \%$ na amostra. A partir destes resultados, observamos maiores problemas sub-registro nos mais jovens e nem tanto nos idosos, de outro lado a maior representação dos em idade ativa. 
A pesquisa realizou-se pautada pela disponibilidade de fontes existentes atualmente e, por isso, não alcançamos uma amostragem sem viés ao longo do espaço brasileiro. Conseguimos levantar informações das matrículas e/ou classificação para catorze das vinte e uma províncias, envolvendo 69 cidades e chegando a um total de mais de cento e doze mil cativos. Tal amostra representou 7,3\% do total de escravos matriculados no país. O banco de dados formado consiste num dos principais registros nominais em termos da população escrava brasileira. Contudo, a amostra conseguida durante a pesquisa mostrou-se bastante parcial, como podemos notar na Tabela 1, que fornece a população matriculada e amostral das províncias.

O Norte do país teve um único representante: Cametá no Pará. Por outro lado, o Sul e o Oeste revelaram-se proporcionalmente super-representados, por conta da preservação significativa das informações para o Paraná e Goiás, porém houve a lacuna de Santa Catarina e Mato Grosso. Não obstante a boa reprodução da importância relativa do Nordeste e Sudeste na amostra, quando avaliamos a distribuição da população escrava amostral entre as províncias que compõem as regiões, verificamos a ausência de dados para a Corte, Ceará, Rio Grande do Norte e Alagoas e um sub-registro expressivo para a Bahia e Rio de Janeiro. Por fim, São Paulo respondeu por mais de um quarto do total da amostra, enquanto essa província detinha tão-somente $11,0 \%$ da população matriculada, em virtude da maior preservação e facilidade de acesso aos documentos.

Apesar dos problemas de representatividade da amostragem para as províncias, a amostra obtida compreendeu os principais espaços produtivos do país: desde as áreas florestais da Amazônia para exportação da borracha e de cacau até a pecuária da campanha gaúcha, passando pelo sertão, agreste e mata nordestinos, pelo cerrado do interior do país, pelo litoral e floresta atlântica etc. Se, de um lado, não temos informação das áreas açucareiras do recôncavo baiano ou da zona da Mata de Alagoas, de outro há dados com relação à Mata pernambucana e sergipana. De forma semelhante, não dispomos dos municípios cafeeiros do vale do Paraíba fluminense em nossa pesquisa, mas temos muitas informações para o vale paulista. Além da representatividade da província, há diferenças importantes no seu interior, como por exemplo ocorreu no caso do Maranhão com participação matriculada e amostral semelhante, porém não podemos afirmar que São Luís represente a província. Destarte, no referente ao conjunto do país, a amostra revelou uma cobertura bastante expressiva. 
Tabela 1. População escrava Brasileira Segundo a matrícula e a amostra $(1872-1877)$

\begin{tabular}{|c|c|c|c|c|c|}
\hline \multirow{2}{*}{ Províncias } & \multicolumn{2}{|c|}{ Matricula } & \multicolumn{2}{|c|}{ Amostra } & \multirow{2}{*}{$\begin{array}{l}\text { Amostra \% } \\
\text { Matrícula }\end{array}$} \\
\hline & Total & $\%$ & Total & $\%$ & \\
\hline \multicolumn{6}{|l|}{ Norte } \\
\hline Amazonas & 1.183 & 0,1 & - & - & - \\
\hline Pará & 30.989 & 2,0 & 2.895 & 2,6 & 9,3 \\
\hline \multicolumn{6}{|l|}{ Nordeste } \\
\hline Maranhão & 74.939 & 4,8 & 5.325 & 4,8 & 7,1 \\
\hline Piauí & 25.533 & 1,6 & 13.120 & 11,6 & 51,4 \\
\hline Ceará & 33.960 & 2,2 & - & - & - \\
\hline Rio Grande do Norte & 13.484 & 0,9 & - & - & - \\
\hline Paraíba & 27.245 & 1,8 & 1.579 & 1,4 & 5,8 \\
\hline Pernambuco & 93.496 & 6,0 & 8.980 & 8,0 & 9,6 \\
\hline Alagoas & 33.242 & 2,1 & - & - & - \\
\hline Sergipe & 32.974 & 2,1 & 6.572 & 5,8 & 19,9 \\
\hline Bahia & 173.639 & 11,2 & 2.796 & 2,5 & 1,6 \\
\hline \multicolumn{6}{|l|}{ Sudeste } \\
\hline Espírito Santo & 22.738 & 1,5 & 2.963 & 2,6 & 13,0 \\
\hline Corte & 47.260 & 3,1 & - & - & - \\
\hline Rio de Janeiro & 304.744 & 19,7 & 1.497 & 1,3 & 0,5 \\
\hline Minas Gerais & 333.436 & 21,6 & 13.124 & 11,6 & 3,9 \\
\hline São Paulo & 169.964 & 11,0 & 33.713 & 29,9 & 19,9 \\
\hline \multicolumn{6}{|l|}{ Oeste } \\
\hline Goiás & 11.876 & 0,8 & 7.299 & 6,5 & 61,5 \\
\hline Mato Grosso & 7.064 & 0,5 & - & - & - \\
\hline \multicolumn{6}{|l|}{ Sul } \\
\hline Paraná & 10.715 & 0,7 & 7.940 & 7,0 & 74,1 \\
\hline Santa Catarina & 14.730 & 0,9 & - & - & - \\
\hline Rio Grande do Sul & 83.370 & 5,4 & 4.942 & 4,4 & 5,9 \\
\hline TOTAL & 1.546 .581 & 100,0 & 112.745 & 100,0 & 7,3 \\
\hline
\end{tabular}

Fonte: Matrícula. Slenes, 1983: 126.

\section{POPULAÇÃO ESCRAVA}

Do conjunto de mais de cem mil escravos trabalhados, verificamos um perfil demográfico com o predomínio numérico dos homens em relação às mulhe- 
res, assumindo uma razão de sexo de $108^{25}$. Se dividirmos a população pelas regiões brasileiras notamos diferenças significativas, como observado na Tabela 2. A região Norte e a Nordeste apresentaram um menor número de homens relativamente às mulheres, enquanto o Sudeste forneceu a maior razão de sexo (123) em decorrência da presença maior do café nessa região. O Sul e o Oeste detinham uma proporção ligeiramente maior de homens em comparação às mulheres, mas prevalecia o equilíbrio numérico dos dois contingentes. Ao que tudo indica, a menor influência dos anos derradeiros do tráfico africano e o maior fluxo emigratório nas províncias mais ao Norte produziu uma distinção expressiva na composição sexual das populações das regiões.

TABELA 2. RAZÃO DE SEXO E ESTRUTURA ETÁRIA SEGUNDO REGIÕES BRASILEIRAS

\begin{tabular}{|l|c|c|c|c|c|}
\hline \multicolumn{1}{|c|}{ Regiões } & $\begin{array}{c}\text { Razões de } \\
\text { sexo }\end{array}$ & $\begin{array}{c}0 \text { a } 14 \text { anos } \\
\%\end{array}$ & $\begin{array}{c}15 \text { a } 49 \text { anos } \\
\%\end{array}$ & $\begin{array}{c}50 \text { ou mais } \\
\%\end{array}$ & $\begin{array}{c}\text { Razão } \\
\text { criança/mulher }\end{array}$ \\
\hline Oeste & 102 & 33,1 & 59,4 & 7,5 & 1.104 \\
Nordeste & 95 & 30,3 & 63,7 & 6,0 & 899 \\
Norte & 93 & 35,8 & 57,5 & 6,7 & 1.181 \\
Sudeste & 123 & 30,0 & 59,2 & 10,8 & 1.139 \\
Sul & 104 & 33,0 & 61,4 & 5,6 & 1.059 \\
\hline Total & 108 & 30,8 & 61,0 & 8,2 & 1.035 \\
\hline
\end{tabular}

Obs: Razão de sexo é o número de homens por grupo de 100 mulheres. A razão crianças de 0 a 14 anos em relação às mulheres em idade fértil (de 15 a 49 anos) é expressa por mil mulheres. Dos 112.745 escravos analisados, não conseguimos levantar a informação do sexo para 736 e de idade para 1.627.

Outra informação disponível nos dados originários da matrícula é a cor dos escravos. A grande maioria foi assinalada como preta (65,0\% do conjunto) e secundariamente parda $(24,0 \%)$. Os demais mestiços (cabras, mulatos, fulas etc.) representaram quase um décimo do total $(9,9 \%)$. Como já apontado pela historiografia para outros períodos e espaços, as relações familiares dos escravos mostraram-se importantes nessa amostra ${ }^{26}$. Apesar de quase dois terços dos cativos serem solteiros $(65,8 \%)$ e pouco mais de um décimo casados e viúvos $(12,5 \%)$, existiam mais de um quinto de cativos com relações de filho,

25 No conjunto dos matriculados no país, Robert Slenes verificou uma razão de 111 (1983, p. 128), bastante próxima à da nossa amostra.

26 Algumas fontes foram mais específicas das relações familiares do que outras em termos do espaço considerado. A respeito da literatura de demografia e família escrava ver o survey de Flávio Motta, 1999. 
irmão ou eventualmente neto de outro cativo $(21,7 \%)$. Assim, pouco mais de um terço dos cativos viviam em famílias ${ }^{27}$.

No conjunto da amostra, a proporção de crianças de zero a catorze anos de idade entre esses cativos mostrou-se significativa, atingindo $30,8 \%$ enquanto os de 50 ou mais anos representaram tão-somente $8,2 \%$ do total ${ }^{28}$. A grande maioria dos escravos encontrava-se naquele momento em idade ativa $(61,0 \%)$, que consideramos de 15 a 49 anos. Novamente se desagregarmos as informações, verificamos distinções importantes, pois a presença das crianças mostrou-se mais elevada no Sul, no Oeste e no Norte do país. Ao contrário do esperado, as pessoas em idade ativa foram mais representativas no Nordeste do que no Sudeste, que era a área mais dinâmica economicamente ${ }^{29}$. Por fim, os mais idosos foram mais freqüentes no Sudeste.

Para a totalidade da amostra, a capacidade reprodutiva dos escravos revelou-se elevada para esse momento posterior ao final do tráfico africano. A razão criança (de 0 a 14 anos)/ mulher (de 15 a 49 anos) atingiu $1.035^{30}$. Tais patamares mostraram-se assemelhados aos verificados para outras áreas em diferentes períodos, porém algumas áreas destacaram-se mais do que outras ${ }^{31}$. $\mathrm{O}$ Norte, o Oeste e o Sudeste apresentaram os maiores patamares, apesar de distinções no perfil etário das suas populações. A menor razão foi para o Nordeste, em função da elevada presença de mulheres em idade fértil.

As atividades agrícolas compreenderam a maior parte das profissões anotadas dos escravos, totalizando $62,5 \%$ deles $^{32}$. Os domésticos também responde-

27 A variável cor e relação familiar apresentaram uma freqüência bastante expressiva em toda a amostra, alcançando o informe de cor $95,1 \%$ dos cativos e família $92,6 \%$. Ainda havia a informação de aptidão ao trabalho e moralidade, que se mostraram menos frequentes no registro, sendo a primeira existente para três quartos dos escravos da amostra e a segunda para apenas cerca de um terço do total. Mesmo assim no primeiro caso, quatro quintos dos escravos com informação desta variável foram classificados com aptos $(80,0 \%)$. No segundo, a moralidade revelou-se, para os casos que temos o informe, principalmente boa (70,0\%), mas havia também regular ou alguma $(25,0 \%)$ e sofrível $(4,4 \%)$.

28 Em comparação com o resultado da matrícula do conjunto do país notamos participações assemelhadas, pois para o conjunto do país a razão de sexo foi de 111 e as crianças perfizeram 32,5\% e os idosos 7,8\%, ver Slenes, 1983: 128-131.

29 A população entre as províncias nordestinas apresentou distinções expressivas com relação à distribuição etária. Enquanto Pernambuco detinha $28,0 \%$ de crianças, o Piauí esse porcentual atingiu 33,8\%. Marcondes, 2009, capítulos 5 a 7.

30 A razão criança mulher é uma medida aproximada da fecundidade geral da população.

31 Ver por exemplo o Maranhão no meado do século XIX em Marcondes (2005).

32 Entre estas se destacaram a de lavrador, roceiro, campeiro, agricultor, vaqueiro, serviço rural etc. A informação de profissão foi também bastante freqüente na documentação compulsada, atingindo $78,0 \%$ de toda a amostra, mas $92,0 \%$ dos escravos maiores de dez anos de idade. 
ram por uma parcela significativa dos cativos, perfazendo pouco mais de um quarto do total $(27,0 \%)^{33}$. As demais profissões representaram parcelas menores do conjunto escravo. Entre elas destacaram-se a de pedreiro/servente $(2,3 \%)$, fiandeira/rendeira $(2,0 \%)$, carreiro/tropeiro/arrieiro $(1,3 \%)$ e jornaleiro/ganhador $(0,6 \%)$. Como esperado, a agricultura demonstrou a sua importância na ocupação dos escravos nesse momento ${ }^{34}$.

Quando analisamos o perfil demográfico dos escravos envolvidos em atividades agrícolas, verificamos a forte presença de homens (67,7\%). A razão de sexo deles atingiu um patamar muito elevado (210). Por outro lado, nas atividades domésticas preponderam as mulheres, chegando a representar $88,6 \%$ do total. De igual modo, a razão alcançou apenas 13. Deste modo, há uma forte especialização entre os sexos para as atividades agrícolas e domésticas.

\section{ESTRUTURA DA POSSE DE ESCRAVOS}

Como vimos anteriormente, as pesquisas sobre a posse de cativos baseadas em fontes de caráter censitário compreenderam diferentes estudos referentes a lugares bastante diversos ao longo do território brasileiro e, em geral, ao período anterior a $1850^{35}$. Neste artigo, analisamos uma amostra para o conjunto do país na década de 1870, abarcando pouco mais de vinte e cinco mil escravistas brasileiros ${ }^{36}$. Os nossos resultados salientaram, como já observado pela historiografia para outros períodos, a presença elevada de pequenos e médios escravistas. Um indicador dessa condição pode ser observado por meio do número médio de escravos dos proprietários, que chegou a 4,4 cativos por escravista. Corroborando este último resultado, outras medidas de posição reforçaram tal visão: a mediana foi dois e a moda um. Este último subconjunto mostrou-se substancial, pois os proprietários detentores de tão-somente um cativo somaram quase dez mil proprietários, ou seja, mais de um terço de todos os escravistas.

33 Classificamos como domésticas as seguintes profissões: cozinheiro, costureiro, serviço doméstico, mucama, engomadeira, lavadeira, pagem, criada etc.

34 Tal resultado relacionou-se à informação agregada da matrícula, na qual para o conjunto do país $86 \%$ dos escravos residiam no ambiente rural. Assim, não apenas os trabalhadores mais diretamente ligados a agricultura moravam no campo, bem como muitos domésticos.

35 Uma exceção é o estudo de Flávio Motta, Nozoe e Costa, 2004 sobre São Cristovão em 1870 (paróquia do município neutro), baseado numa prévia do censo de 1872.

36 Destes a grande maioria eram homens $(78,4 \%$ do total), mas havia pouco mais de um quinto de mulheres $(20,8 \%)$. Por fim, ainda existiam companhias e instituições religiosas, que detinham quase um ponto porcentual $(0,7 \%)$. 
O terceiro quartel do século XIX constituiu um momento de expansão cafeeira pelo Sudeste brasileiro, incorporando novas áreas produtivas, até mesmo em função de preços e condições favoráveis de transportes e beneficiamento. As exportações cresceram no período, acompanhadas pela maior demanda por mão-de-obra, que não pode ser mais atendida pelo tráfico africano, apenas pela disponibilidade interna, já que a grande imigração européia iniciou-se somente na década seguinte. Entretanto, a estrutura produtiva apresentada por estes novos dados da posse de cativos ainda demonstra patamares de posses bastante reduzidos para estas áreas cafeeiras e mesmo para o conjunto brasileiro. Por outro lado, a difusão da posse revelou-se muito expressiva e por todo o território brasileiro. Se a posse média calculada nesta amostra for aceitável para a totalidade do território, podemos estimar que no início da década de 1870 deveria existir cerca de 350 mil escravistas no país. Se suas famílias compreendessem geralmente de 4 a 6 pessoas, provavelmente o total de pessoas livres que viviam com a presença de escravos chegava de $16,3 \%$ a $24,4 \%{ }^{37}$. Uma a cada quatro ou cinco famílias brasileiras mantinham escravos, apesar de serem poucos. Deste modo, entendemos de melhor forma a resistência à abolição da escravatura no país.

A distribuição dos escravos pelos seus proprietários revelou, no seu todo, uma concentração bastante elevada, chegando o índice de Gini a $0,576^{38}$. Como observamos na Tabela 3, quatro quintos dos plantéis continham menos de seis cativos, porém eles detinham pouco mais de um terço do total dos escravos. Havendo de seis a vinte pessoas em suas escravarias, os escravistas médios representaram um pouco mais de um sexto do seu conjunto, contudo mantinham quase quatro décimos dos cativos. Por fim, os grandes proprietários com vinte e um ou mais elementos em seus plantéis totalizaram tão-somente três por cento. Contudo, estes possuíam mais de um quarto do total dos escravos.

37 Utilizamos o censo de 1872/74 como indicador do total de escravos e de pessoas livres no país. Tais estimativas são bastante conservadoras para a posse média, que provavelmente seria menor para o país do que a calculada nesta pesquisa. De outro lado, as famílias poderiam compreender um maior número de pessoas em seus domicílios. Como o total de fogos no censo foi de 1.336 mil, podemos estimar os domicílios escravistas representando $25,7 \%$ do total.

38 Francisco Vidal Luna esclarece: «O índice de Gini corresponde a um coeficiente estatístico, largamente utilizado para medir concentração de renda ou riqueza. Constitui, na verdade, a relação entre áreas de um quadrado, construído de forma a representar, num dos eixos (o horizonte), a população segmentada em percentis e no outro (o vertical), a riqueza ou renda (também dividida em percentis) da coletividade estudada. (...) Dessa forma, quanto mais regularmente se distribui a renda ou riqueza, mais próximo de zero estará o valor do índice (zero no limite); correlativamente, quanto mais concentrada estiver a riqueza ou renda, maior será o valor do aludido índice que, no máximo, iguala-se à unidade». Luna, 1981: 121. Utilizamos a variável posse de escravos como uma proxy da variável riqueza. 
Tabela 3. Estrutura da posse de cativos da amostra

\begin{tabular}{|c|r|r|r|r|}
\hline \multirow{2}{*}{ FTP } & \multicolumn{2}{|c|}{ Proprietários } & \multicolumn{2}{c|}{ Escravos } \\
\cline { 2 - 5 } & Número & $\%$ & Número & \multicolumn{1}{c|}{$\%$} \\
\hline 1 & 9.891 & 38,7 & 9.891 & 8,8 \\
2 a 5 & 10.631 & 41,5 & 31.787 & 28,2 \\
6 a 10 & 2.984 & 11,7 & 22.400 & 19,9 \\
11 a 20 & 1.391 & 5,4 & 19.556 & 17,3 \\
21 a 40 & 496 & 1,9 & 13.932 & 12,3 \\
41 a 100 & 178 & 0,7 & 10.445 & 9,3 \\
101 ou mais & 27 & 0,1 & 4.718 & 4,2 \\
\hline TOTAL & 25.598 & 100,0 & 112.729 & 100,0 \\
\hline
\end{tabular}

Obs: FTP = faixas de tamanho dos plantéis. Nesta tabela, consideramos tão-somente os casos com o nome do proprietário determinado, desconsiderando 16 casos de escravos.

Como observado na literatura para a década de 1830, os plantéis gigantes com mais de uma centena de cativos constituíram em quase uma exceção, atingindo vinte e sete unidades, das quais tão-somente duas se situaram fora de São Paulo: um em Cabo (PE) e outro Inhambupe (BA) ${ }^{39}$. Na província paulista, a distribuição concentrou-se nas principais áreas cafeeiras: Bananal detinha dezesseis deles e Limeira, quatro. Embora fossem menos de três dezenas de pessoas, elas abarcaram quase cinco mil escravos. Entre eles o maior plantel chegou a compreender 419 pessoas, possuídos pela Vergueiro \& Companhia de Limeira ${ }^{40}$. Desse modo, nessa nova área de cultivo do café, o porte das propriedades escravas alcançou, ainda na fase de difusão dos cafeeiros pelos seus terrenos, um padrão muito elevado. Assim, os plantéis gigantes concentraram-se nas principais áreas cafeeiras do país nesse momento.

As ocupações desses escravistas não foram registradas na classificação ou matrícula, porém podemos verificar, de forma ilustrativa, a profissão declarada pela população livre no censo de 1872-74. A metade desse contingente foi recenseada como lavradores $(49,8 \%)$. Ainda houve certo destaque para o serviço doméstico e o artesanato, apresentando participação de $23,4 \%$ e $17,7 \%$, respectivamente. Por fim, o comércio alcançou três por cento dos livres.

39 Luna \& Klein observaram três grandes plantéis na década de 1830 com mais de trezentos cativos em Minas Gerais, sendo um deles a Imperial Companhia de Mineração. Em São Paulo, o maior escravista detinha 164 pessoas (2004: 9).

40 Em Campinas, Slenes verificou, referente a década de 1870, a presença de cinco escravarias compreendendo cem ou mais escravos, cf. Slenes, 1998: 77. 
A comparação ao longo do século XIX apontou um quadro de redução em termos absolutos da população escrava brasileira e das posses médias cativas, principalmente quando confrontamos os nossos dados e os fornecidos pela historiografia para o início desse século, calcados em listas nominativas de habitantes. O número médio de escravos revelou-se nos censos da década de 1830 para Minas Gerais igual a 6,6, para São Paulo 7,2 e para o Paraná 5,141 e para o recôncavo baiano 8,8 — cf. Barickman, 2003: 55-56 — ${ }^{42}$. Quando consideramos tão-somente as nossas informações para os municípios selecionados destas áreas, as médias para a década de 1870 atingiram os seguintes valores: 3,7 para Minas Gerais, 6,6 para São Paulo, 3,2 para o Paraná e 5,0 para a Bahia. Assim, apesar das diferenças nos espaços analisados, consolidou-se a tendência de retração das propriedades ao longo do século XIX para essas províncias. Esse resultado pode derivar, pelo menos em parte, das restrições impostas ao tráfico africano a partir do segundo quartel do século. $\mathrm{O}$ avanço proporcionalmente maior da cafeicultura atenuou a redução da propriedade cativa na área paulista e provavelmente demais áreas cafeeiras. Por fim, a desigualdade da posse parece ter aumentado tão-somente para São Paulo, ocorrendo o inverso para o Paraná e Minas Gerais ${ }^{43}$.

Em termos de regiões, podemos observar a distribuição da posse de cativos na Tabela 4. As posses mostram-se mais reduzidas no Oeste e Sul do país, atingindo valores médios inferiores a quatro cativos. Ademais, estas regiões mantinham os menores índices de Gini de toda a amostra, apontando uma concentração mais reduzida. O Nordeste apresentou uma média um pouco mais elevada, ligeiramente superior a quatro. Por fim, o Sudeste detinha a média e o Gini mais elevados, em grande parte decorrência da faina cafeicultora ${ }^{44}$.

Apesar do grande desenvolvimento cafeeiro e do dinamismo de outras culturas e atividades direcionadas tanto para o mercado interno quanto para o externo na década de 1870 , o padrão da posse de cativos mostrou-se reduzido, com a presença de elevado número de pequenos escravistas. Em contrapartida, os resultados assinalaram também uma desigualdade expressiva da distribui-

41 Cf. Luna \& Klein, 2004: 10.

42 Esse último cômputo é nosso a partir das informações desagregadas do autor. Contamos 796 escravistas que possuíam 7.045 escravos em duas freguesias do Recôncavo baiano, sendo uma açucareira e outra de, sobretudo, fumo.

43 O índice de Gini para os 1830s foi de 0,574 para Minas Gerais, 0,596 para São Paulo e 0,527 para o Paraná. Luna \& Klein, 2004: 9. Na nossa amostra, tal indicador chegou a 0,660 para São Paulo, 0,510 para Minas Gerais e 0,484 para o Paraná.

44 Nesse momento, o número médio de escravos e o índice de Gini das localidades apresentaram uma elevada correlação $(0,819)$. 
TABELA 4. INDICADORES DA POSSE DE CATIVOS DAS REGIÕES

\begin{tabular}{|l|r|r|c|c|c|c|}
\hline \multicolumn{1}{|c|}{ Regiões } & Escravistas & Cativos & Média & Máximo & $\begin{array}{c}\text { Coeficiente } \\
\text { de Variação }\end{array}$ & Gini \\
\hline Oeste & 2.213 & 7.299 & 3,3 & 59 & 1,18 & 0,477 \\
Nordeste & 9.433 & 38.370 & 4,1 & 194 & 1,69 & 0,565 \\
Norte & 594 & 2.895 & 4,9 & 61 & 1,22 & 0,508 \\
Sudeste & 9.574 & 51.283 & 5,4 & 419 & 2,43 & 0,618 \\
Sul & 3.784 & 12.882 & 3,4 & 66 & 1,15 & 0,482 \\
\hline Total & 25.598 & 112.729 & 4,4 & 419 & 2,10 & 0,576 \\
\hline
\end{tabular}

ção dos cativos entre seus proprietários, cidades, províncias e até mesmo regiões. Assim, podemos observar uma pirâmide social dos livres formada de poucos grandes proprietários, vários médios e muitos pequenos escravistas, além do contingente mais numeroso de não-proprietários de escravos.

O Brasil escravocrata na década de 1870 marcou-se comumente por um mundo de senhores de poucas posses, em geral um, dois, três ou quatro. Este quadro ajuda a explicar estrutura arraigada da escravidão em nosso país, demonstrado pela resistência em eliminar a escravidão. $\mathrm{O}$ apego não se originava somente de um reduzido grupo de grandes escravistas, mas também de uma multidão de pequenos escravistas. De outro lado, houve uma vivência mais próxima entre senhores e escravos, especialmente nos menores plantéis. $\mathrm{O}$ cotidiano da escravidão nestas condições deixava frente a frente estes indivíduos. A interação possibilitou formas variadas de relações pessoais desde as mais amenas até as mais cruéis, cordialmente demarcadas por laços de amizade/inimizade, amor/ódio etc.

No apêndice do artigo reunimos os indicadores das posses de todos os municípios analisados, assim poderemos entender melhor a conformação das disparidades da propriedade ao longo do espaço, relacionando às condições socioeconômicas e até geográficas destas localidades ${ }^{45}$. Apesar das posses signi-

45 Uma alternativa seria agregar as localidades em grupos por meio dos indicadores de posses, facilitando a comparabilidade. A partir disso procuramos estabelecer grupos de localidades de acordo com as distribuições da posse dos cativos por meio de uma técnica tradicional das ciências sociais: a análise de cluster. Num outro trabalho, utilizamos as seguintes variáveis: as participações relativas dos escravos nas seis faixas de tamanho dos plantéis estabelecidas na seção anterior, o índice de Gini e a média de escravos de cada uma das localidades. Optamos por padronizar as médias de 0 a 1 a fim de mantermos escalas idênticas das variáveis em questão. $\mathrm{O}$ método de cluster hierárquico empregado foi o de Ward. O resultado apontou 13 grupos de localidades, salientando a diversidade da realidade brasileira no momento (ver Marcondes, 2009). 
ficativas em áreas pouco relacionadas ao café, a influência direta ou indireta da cafeicultura determinou grande divergência entre as localidades em estudo, atingindo posses elevadas nas localidades paulistas de Bananal e Limeira, que detinham expressiva atividade de produção e exportação de cafét ${ }^{46}$. Tal disparidade não se restringiu a apresentar ou não o seu cultivo, pois o seu papel não se revelou igual em cada um dos locais que se cultivou a preciosa rubiácea. A força da plantation cafeeira dos grandes centros produtores conviveu com cidades nas quais a pequena e a média cafeicultura ganharam destaque, produzindo perfis de posses distintos ${ }^{47}$. Ao realizarmos a discussão de um momento da localidade em sua história de cultivo do café, capturamos a realidade daquele estágio do ciclo produtivo. Como vimos acima, as condições de produção revelaram-se diversas, podendo aproximar cidades, em fases cafeeiras diferentes. Não obstante este privilégio que concedemos ao café, verificamos a grande atração de outros produtos pela economia cafeeira e a sua dependência dessas mercadorias, no caso das nacionais, desde os cereais nas áreas vizinhas a, até mesmo, os animais das mais distantes ${ }^{48}$. Assim, o comércio integra áreas de distintas produções, favorecendo a especialização.

Além das distinções no espaço, havia importantes diferenças da composição do plantel de escravos em virtude do porte dos escravistas, como visto na Tabela 5. A primeira diferenciação foi com relação ao sexo dos escravos, pois os plantéis menores apresentaram um maior número de mulheres em comparação com os de homens. De outro lado, os plantéis mais numerosos mostraram uma desproporção em favor dos homens. Destarte, as razões de sexo mostraram-se crescentes de acordo com a faixa de tamanho de plantel.

A distribuição etária revelou um resultado não tão direto. Os plantéis intermediários apresentaram a maior presença relativa de crianças e maiores razões criança/mulher ${ }^{49}$. Os idosos elevaram sua participação à medida que cresce-

46 Até mesmo em Bananal que detinha a maior posse média de toda a pesquisa $(15,1)$, os escravistas possuidores de um escravo representavam 29,3\% do total. Mais da metade dos proprietários de Bananal detinham até cinco escravos (61,4\% deles).

47 Mesmo nos grandes centros produtores, havia a presença de pequenos cafeicultores e escravistas.

48 Uma visão dessa mútua dependência da produção para a exportação e o mercado interno pode ser observada na obra de Bert J. Barickman (2003) para o Recôncavo baiano entre a mandioca, fumo e açúcar.

49 Devemos analisar com muito cuidado as informações da razão criança/mulher para os plantéis unitários, pois o potencial reprodutivo dependeria das relações entre escravos de diferentes plantéis. Embora existam relatos da existência de tais vínculos principalmente no meio urbano, esta possibilidade deve ser menos provável do que as relações reprodutivas dentro de um mesmo plantel. 
Tabela 5. Composição dos Plantéis SEgundo A ESTRUtura da POSSE de CATivos DA AMOSTRA

\begin{tabular}{|c|c|c|c|c|c|c|c|}
\hline \multirow[b]{2}{*}{ FTP } & \multirow{2}{*}{$\begin{array}{l}\text { Razão de } \\
\text { Sexo }\end{array}$} & \multicolumn{3}{|c|}{ Razão criança (\%) } & \multirow{2}{*}{$\begin{array}{c}\text { Razão } \\
\text { criança/ } \\
\text { mulher }\end{array}$} & \multirow[b]{2}{*}{$\begin{array}{c}\% \\
\text { Lavoura }\end{array}$} & \multirow[b]{2}{*}{ \% Dome } \\
\hline & & $\begin{array}{c}0 \text { a } 14 \\
\text { anos }\end{array}$ & $\begin{array}{c}15 \text { a } 49 \\
\text { anos }\end{array}$ & $\begin{array}{l}50 \text { anos } \\
\text { ou mais }\end{array}$ & & & \\
\hline 1 & 82 & 21,0 & 72,4 & 6,6 & 519 & 50,1 & 39,6 \\
\hline 2 a 5 & 90 & 32,0 & 61,5 & 6,5 & 949 & 54,5 & 35,4 \\
\hline 6 a 10 & 108 & 36,0 & 56,9 & 7,1 & 1.285 & 62,6 & 27,6 \\
\hline 11 a 20 & 117 & 32,9 & 59,1 & 8,0 & 1.207 & 67,1 & 22,7 \\
\hline 21 a 40 & 137 & 29,4 & 60,4 & 10,2 & 1.167 & 71,8 & 17,6 \\
\hline 41 a 100 & 140 & 27,5 & 60,6 & 11,9 & 1.133 & 74,3 & 14,6 \\
\hline 101 ou mais & 149 & 21,9 & 62,7 & 15,4 & 881 & 73,8 & 9,7 \\
\hline TOTAL & 108 & 30,8 & 61,0 & 8,2 & 1.035 & 62,5 & 27,0 \\
\hline
\end{tabular}

Obs.: FTP $=$ faixas de tamanho dos plantéis. Dome $=$ Domésticos.

ram as escravarias. Por fim, a participação relativa dos lavradores também aumentou em razão da elevação das posses, em detrimento dos domésticos. Estes últimos perfizeram quatro décimos nos plantéis unitários.

\section{CONSIDERAÇÕES FINAIS}

A amostra compulsada retrata uma parcela expressiva do território e da população escrava brasileira. Apesar de um momento bastante posterior ao final do tráfico africano de escravos, ainda há a predominância dos cativos do sexo masculino e em idade ativa, como apontado na literatura por meio de outras fontes e principalmente para períodos anteriores. Como esperado para uma sociedade rural, as profissões relacionadas à agricultura revelaram-se mais freqüentes do que aos serviços domésticos. Em termos do espaço, notamos a maior razão de sexo na região Sudeste. Por outro lado, nas demais verificamos um maior equilíbrio numérico entre os sexos e uma razão criança/mulher também elevada, à exceção do Nordeste que apresentou uma menor capacidade reprodutiva.

Os novos resultados fornecidos neste artigo reforçam a importância da pequena e da média propriedade escrava e da elevada desigualdade das posses. Ao analisarmos um conjunto muito amplo de informações referentes a distintas realidades brasileiras, verificamos para todas elas ampla preeminência numérica dos proprietários de um, dois, três ou quatro cativos no seu conjunto. Até mesmo em áreas de grande presença da atividade exportação, seja com o 
café ou o açúcar, não modificaram o quadro geral, mantendo apenas posses mais elevadas e maior presença de grandes plantéis. Apesar dos pequenos escravistas serem muitos, eles não detinham a maioria dos escravos, mas não podem ser desconsiderados, pois compreenderam quase um terço do total. As posses e a desigualdade revelaram-se maiores no Sudeste em comparação com o Sul e Oeste. O Nordeste mostrou um perfil intermediário em relação às demais. Por fim, o Norte aproximou-se da realidade das posses do Sudeste, mas um pouco menor. Destarte, a grande diversidade brasileira revelou-se já na década de 1870 ao analisarmos a propriedade escrava, acompanhada de uma desigualdade também elevada.

\section{REFERÊNCIAS BIBLIOGRÁFICAS}

Alves, Maurício Martins, Forjando igualdades na diferença: socialização parental entre cativos em Taubaté, 1680-1848, Tese (Doutorado em História), IFCS/UFRJ, 2001.

Andreoni, João Antônio, Cultura e opulência do Brasil, 3. ${ }^{a}$ ed., Belo Horizonte, Itatiaia/Edusp, 1982.

Barbosa, Rui, Emancipação dos escravos: o projeto Dantas (dos sexagenários) e o parecer que o justifica, Rio de Janeiro, Casa de Rui Barbosa, 1988.

Barickman, Bert J., Um contraponto baiano: açúcar, fumo, mandioca e escravidão no Recôncavo, 1780-1860, Rio de Janeiro, Civilização Brasileira, 2003.

Castro, Hebe Maria da Costa Mattos Gomes de \& Eduardo Schnoor, Resgate: uma janela para o oitocentos, Rio de Janeiro, Topbooks, 1995.

Costa, Iraci del Nero da, Arraia-miuda: um estudo sobre os não-proprietários de escravos no Brasil, Belo Horizonte, MGSP, 1992.

Costa, Iraci del Nero da \& Nelson Hideiki Nozoe, «Elementos da estrutura de posse de escravos em Lorena no alvorecer do século XIX», Estudos Econômicos, v. 19, n. 2 (São Paulo, mai./ago., 1989): 319-345.

Diretoria Geral de Estatística (DGE), Recenseamento Geral do Império de 1872, Rio de Janeiro, Typ. Leuzinger/Tip. Commercial, 1876, 12 volumes.

Falci, Miridan Britto Knox, Escravos do sertão: demografia, trabalho e relações sociais, Teresina, Fundação Cultural Monsenhor Chaves, 1995.

Frank, Zephyr L, «Padrões de riqueza no Sudeste do Brasil: 1815-1860», História Econômica \& História de Empresas, vol. IX, n. 2 (São Paulo, jul./dez 2006): 5-48.

Freyre, Gilberto, Casa-grande \& senzala: formação da família brasileira sob o regime da economia patriarcal, São Paulo, Círculo do Livro, 1986. 
Funes, Eurípides Antônio, Goiás 1800-1850: um período de transição da mineração à agropecuária, Goiânia, Ed. da Universidade Federal de Goiás, 1986.

Furtado, Celso M, Formação Econômica do Brasil, 27. a ed., São Paulo, Companhia Editora Nacional/Publifolha, 2000.

Galliza, Diana Soares de, O declínio da escravidão na Paraíba (1850-1888), João Pessoa, Universitária/UFPb, 1979.

Graf, Márcia Elisa de Campos, População escrava da província do Paraná: a partir das listas de classificação para emancipação, 1873 e 1886, Dissertação (Mestrado em História), SCHLA/UFPR, 1974.

Graham, Richard, «Escravidão e desenvolvimento econômico: Brasil e Sul dos Estados Unidos no século XIX», Estudos Econômicos, 13/1 (São Paulo, jan./mar. 1983): 223-257.

Holanda, Sérgio Buarque de, Raízes do Brasil, 26. a ed., Rio de Janeiro, Editora José Olympio, 1994.

Kühn, Fábio, Capitulos de História do Rio Grande do Sul, Porto Alegre, Editora da UFRGS, 2004.

Kühn, Fábio, Gente da fronteira: família, sociedade e poder no sul da América Portuguesa - século XVIII, Tese (Doutorado em História), ICHF/UFF, 2006.

Luna, Francisco Vidal, Minas Gerais: escravos e senhores - análise da estrutura populacional e econômica de alguns centros mineratórios (1718-1804), São Paulo, IPE-USP, 1981.

Luna, Francisco Vidal \& Hebert S. Klein, «Slave economy and Society in Minas Gerais and São Paulo, Brazil in 1830», Journal of Latin American Studies, 36/1 (Londres, fev. 2004): 1-28.

Marcílio, Maria Luiza, A cidade de São Paulo: povoamento e população 1750-1850 com base nos registros paroquiais e nos recenseamentos antigos, São Paulo, Pioneira/Edusp, 1974.

Marcondes, Renato Leite, «Posse de Cativos no Interior do Maranhão (1848)», Revista do Instituto Arqueológico, Histórico e Geográfico Pernambucano, 61 (Recife, 2005): 169-186.

Marcondes, Renato Leite, Diverso e desigual: o Brasil escravista na década de 1870, Ribeirão Preto, Funpec, 2009.

Mott, Luiz Roberto de Barros, Piauí colonial: população, economia e sociedade, Teresina, Projeto Petrônio Portella/Fundação Cultural do Estado do Piauí, 1985.

Motta, José Flávio, Corpos escravos, vontades livres: posse de cativos e família escrava em Bananal (1801-1829), São Paulo, Annablume/Fapesp, 1999. 
Motta, José Flávio, «The historical demography of Brazil at the V centenary of its discovery», Ciência e Cultura: Journal of the Brazilian Association for the Advancement of Science, 51/5-6 (set./dec. 1999): 446-456.

Motta, José Flávio; Nelson Nozoe \& Iraci del Nero da Costa, «Às vésperas da aboli ção - um estudo sobre a estrutura da posse de escravos em São Cristóvão (RJ), 1870», Estudos Econômicos, 24/1 (São Paulo, jan./mar. 2004): 157-213.

Nadalin, Sergio Odilon, História e demografia: elementos para um diálogo, Campinas, Associação Brasileira de Estudos Populacionais (ABEP), 2004.

Oliveira, João Alfredo Corrêa de, Relatório apresentado a Assembléia Geral Legislativa na $4 .{ }^{a}$ Sessão da $15 .{ }^{a}$ Legislatura pelo Ministro e Secretario de Estado dos Negócios do Império, Rio de Janeiro, Tipografia Nacional, 1875.

Paiva, Clotilde Andrade \& Douglas Cole Libby, «Caminhos alternativos: escravidão e reprodução em Minas Gerais no século XIX», Estudos Econômicos, 25/2 (São Paulo, mai./ago. 1995): 203-233.

Paiva, Clotilde Andrade, População e economia nas Minas Gerais do século XIX, Tese (Doutorado em História), FFLCH/USP, 1996.

Passos Subrinho, Josué Modesto dos, «Escravos e senhores no crepúsculo do escravismo: Laranjeiras, província de Sergipe», Anais do XXV Encontro Nacional de Economia, ANPEC, v. 2 (Recife, 1997): 995-1014.

Pena, Eduardo Spiller, O jogo da face: a astúcia escrava frente aos senhores e à lei na Curitiba provincial, Curitiba, Aos quatro ventos, 1999.

Prado Jr., Caio, Formação do Brasil Contemporâneo (colônia), 17. a ed., São Paulo, Brasiliense, 1981.

Schwartz, Stuart B, Segredos internos: engenhos e escravos na sociedade colonial, São Paulo, Cia. das Letras/CNPq, 1988.

Slenes, Robert Wayne, «O que Rui Barbosa não queimou: novas fontes para o estudo da escravidão no século XIX», Estudos Econômicos, 13/1 (São Paulo, jan./abr. 1983): 117-149.

Slenes, Robert Wayne, «A formação da família escrava nas regiões de grande lavoura do Sudeste: Campinas um caso paradigmático no século XIX», População e Família, 1/1 (São Paulo, jan./jun. 1998): 9-82.

Valentin, Agnaldo, Nem Minas, nem São Paulo: economia e demografia na localidade paulista de Apiai (1732-1835), Dissertação (Mestrado em História), FFLCH-USP, 2001.

Fecha de recepción: 14-4-2010

Fecha de aceptación: 20-6-2010 


\section{APÊNDICE}

Tabela AP.1. Posse de Cativos das localidades Segundo suas províncias $(1872-1877)$

\begin{tabular}{|c|c|c|c|c|c|c|c|}
\hline Localidades & Proprietários & Escravos & Média & D.P. & C.V. & Gini & Fonte \\
\hline \multicolumn{8}{|l|}{ Goiás } \\
\hline Arraias & 166 & 551 & 3,3 & 5,0 & 1,51 & 0,489 & $\mathrm{M}$ e $\mathrm{C}$ \\
\hline Boa Vista & 66 & 288 & 4,4 & 7,5 & 1,71 & 0,514 & M \\
\hline Bonfim & 252 & 842 & 3,3 & 3,5 & 1,05 & 0,471 & M \\
\hline Catalão & 366 & 1.105 & 3,0 & 3,1 & 1,01 & 0,457 & M \\
\hline Entre Rios & 110 & 400 & 3,6 & 3,7 & 1,01 & 0,476 & M \\
\hline Flores & 45 & 135 & 3,0 & 2,1 & 0,70 & 0,371 & M \\
\hline Formosa & 131 & 486 & 3,7 & 3,8 & 1,04 & 0,447 & M \\
\hline Goiás & 385 & 1.085 & 2,8 & 3,2 & 1,12 & 0,461 & $\mathrm{M}$ e $\mathrm{C}$ \\
\hline Jaraguá & 70 & 245 & 3,5 & 5,5 & 1,56 & 0,544 & M \\
\hline Meia Ponte & 146 & 454 & 3,1 & 3,5 & 1,13 & 0,458 & $\mathrm{M}$ \\
\hline Natividade & 75 & 222 & 3,0 & 2,6 & 0,89 & 0,421 & M \\
\hline Pilar & 110 & 271 & 2,5 & 2,0 & 0,81 & 0,399 & M \\
\hline Rio Verde & 171 & 809 & 4,7 & 5,6 & 1,18 & 0,526 & $\mathrm{M}$ e $\mathrm{C}$ \\
\hline Santa Luzia & 120 & 406 & 3,4 & 3,1 & 0,93 & 0,453 & M \\
\hline \multicolumn{8}{|l|}{ Maranhão } \\
\hline São Luís & 1.690 & 5.325 & 3,2 & 4,2 & 1,34 & 0,488 & C \\
\hline \multicolumn{8}{|l|}{ Piauí } \\
\hline Barras & 308 & 1.070 & 3,5 & 4,8 & 1,38 & 0,537 & $\mathrm{C}$ \\
\hline Batalha & 117 & 412 & 3,5 & 4,1 & 1,16 & 0,494 & $\mathrm{C}$ \\
\hline Humildes & 97 & 215 & 2,2 & 1,9 & 0,86 & 0,379 & $\mathrm{C}$ \\
\hline Jaicós & 751 & 2.545 & 3,4 & 4,6 & 1,35 & 0,534 & $\mathrm{C}$ \\
\hline Oeiras & 434 & 1.939 & 4,5 & 5,6 & 1,26 & 0,522 & $\mathrm{C}$ \\
\hline Parnaíba & 253 & 643 & 2,5 & 3,4 & 1,34 & 0,476 & $\mathrm{C}$ \\
\hline Piracuruca e Pedro II & 254 & 768 & 3,0 & 3,9 & 1,28 & 0,462 & $\mathrm{C}$ \\
\hline Teresina & 538 & 2.770 & 5,2 & 7,1 & 1,38 & 0,561 & $\mathrm{C}$ \\
\hline União & 151 & 762 & 5,1 & 8,8 & 1,74 & 0,612 & $\mathrm{C}$ \\
\hline Valença & 529 & 1.996 & 3,8 & 4,7 & 1,24 & 0,518 & $\mathrm{C}$ \\
\hline \multicolumn{8}{|l|}{ Paraíba } \\
\hline Bananeiras & 230 & 706 & 3,1 & 3,08 & 1,00 & 0,453 & C \\
\hline Cajazeiras & 178 & 345 & 1,9 & 1,41 & 0,73 & 0,338 & $\mathrm{C}$ \\
\hline Misericórdia & 226 & 528 & 2,3 & 2,30 & 0,99 & 0,424 & $\mathrm{C}$ \\
\hline \multicolumn{8}{|l|}{ Pernambuco } \\
\hline Cabo & 527 & 4.207 & 8,0 & 15,07 & 1,89 & 0,651 & $\mathrm{C}$ \\
\hline Olinda & 215 & 761 & 3,5 & 7,02 & 1,98 & 0,566 & $\mathrm{C}$ \\
\hline Palmares & 692 & 4.012 & 5,8 & 8,31 & 1,43 & 0,575 & $\mathrm{C}$ \\
\hline \multicolumn{8}{|l|}{ Bahia } \\
\hline Inhambupe & 401 & 2.041 & 5,1 & 9,5 & 1,87 & 0,606 & $\mathrm{C}$ \\
\hline Ilhéus & 155 & 755 & 4,9 & 9,1 & 1,85 & 0,627 & C \\
\hline \multicolumn{8}{|l|}{ Sergipe } \\
\hline Capela & 627 & 2.678 & 4,3 & 7,5 & 1,75 & 0,581 & $\mathrm{C}$ \\
\hline Lagarto & 474 & 1.794 & 3,8 & 5,2 & 1,38 & 0,540 & $\mathrm{C}$ e $\mathrm{R}$ \\
\hline Laranjeiras & 450 & 1.613 & 3,6 & 7,1 & 1,99 & 0,614 & $\mathrm{C}$ \\
\hline Simão Dias & 136 & 485 & 3,6 & 3,6 & 1,01 & 0,474 & $\mathrm{C}$ \\
\hline
\end{tabular}


Tabela AP.1. Posse de cativos das localidades segundo suas províncias $(1872-1877)$

(Continuacão)

\begin{tabular}{|c|c|c|c|c|c|c|c|}
\hline Localidades & Proprietários & Escravos & Média & D.P. & C.V. & Gini & Fonte \\
\hline \multicolumn{8}{|l|}{ Pará } \\
\hline Cametá & 594 & 2.895 & 4,9 & 5,9 & 1,22 & 0,508 & $\mathrm{C}$ \\
\hline Rio Grande do Sul & & & & & & & \\
\hline Dom Pedrito & 377 & 1.490 & 4,0 & 3,5 & 0,90 & 0,442 & $\mathrm{C}$ e $\mathrm{R}$ \\
\hline Encruzilhada & 657 & 2.429 & 3,7 & 3,7 & 1,00 & 0,466 & $\mathrm{C}$ \\
\hline Rio Pardo & 236 & 1.023 & 4,3 & 4,5 & 1,06 & 0,506 & $\mathrm{C}$ e $\mathrm{R}$ \\
\hline \multicolumn{8}{|l|}{ Paraná } \\
\hline $\begin{array}{c}\text { Antonina, Morretes } \\
\text { e Guaratuba }\end{array}$ & 38 & 1.038 & 2,7 & 2,7 & 1.02 & 0.441 & C \\
\hline Castro & 328 & 1.376 & 4,2 & 6,7 & 1,59 & 0,547 & $\mathrm{C}$ \\
\hline Comarca de Curitiba & 813 & 2.053 & 2,5 & 2,4 & 0,96 & 0,424 & $\mathrm{C}$ \\
\hline Lapa e Rio Negro & 248 & 1.021 & 4,1 & 4,6 & 1,12 & 0,506 & $\mathrm{C}$ e $\mathrm{R}$ \\
\hline Palmeira & 164 & 475 & 2,9 & 3,0 & 1,02 & 0,456 & $\mathrm{C}$ e $\mathrm{R}$ \\
\hline Paranaguá & 221 & 659 & 3,0 & 3,6 & 1,19 & 0,470 & $\mathrm{C}$ \\
\hline Ponta Grossa e Tibagy & 354 & 1.318 & 3,7 & 4,2 & 1,12 & 0,497 & $\mathrm{C}$ e $\mathrm{R}$ \\
\hline \multicolumn{8}{|l|}{ Espírito Santo } \\
\hline Vitória & 554 & 2.963 & 5,4 & 7,6 & 1,42 & 0,564 & $\mathrm{C}$ \\
\hline \multicolumn{8}{|l|}{ Minas Gerais } \\
\hline Dores da Marmelada & 479 & 1.252 & 2,6 & 3,4 & 1,28 & 0,457 & $\mathrm{C}$ \\
\hline Ouro Preto & 603 & 2.384 & 4,0 & 5,3 & 1,33 & 0,535 & $\mathrm{C}$ e $\mathrm{R}$ \\
\hline Paracatu & 356 & 1.185 & 3,3 & 3,3 & 0,98 & 0,449 & $\mathrm{C}$ \\
\hline Patos & 355 & 1.230 & 3,5 & 3,6 & 1,03 & 0,473 & $\mathrm{C}$ \\
\hline Ponte Nova & 1.296 & 5.585 & 4,3 & 5,7 & 1,32 & 0,527 & $\mathrm{C}$ \\
\hline Santo Antonio do Monte & 490 & 1.475 & 3,0 & 3,5 & 1,15 & 0,473 & $\mathrm{C}$ \\
\hline \multicolumn{8}{|l|}{ Rio de Janeiro } \\
\hline Parati & 350 & 1.497 & 4,3 & 6,3 & 1,48 & 0,555 & $\mathrm{C}$ \\
\hline \multicolumn{8}{|l|}{ São Paulo } \\
\hline Amparo & 251 & 1.889 & 7,5 & 11,9 & 1,58 & 0,575 & $\mathrm{C}$ e $\mathrm{R}$ \\
\hline Bananal & 498 & 7.536 & 15,1 & 38,9 & 2,57 & 0,759 & $\mathrm{C}$ \\
\hline Batatais & 486 & 2.361 & 4,9 & 8,5 & 1,74 & 0,587 & $\mathrm{C}$ \\
\hline Iguape & 392 & 1.539 & 3,9 & 4,7 & 1,20 & 0,504 & $\mathrm{C}$ \\
\hline Itu & 612 & 3.397 & 5,6 & 11,9 & 2,15 & 0,660 & $\mathrm{C}$ e $\mathrm{R}$ \\
\hline Limeira & 338 & 3.274 & 9,7 & 28,5 & 2,94 & 0,718 & $\mathrm{C}$ \\
\hline Lorena e Cruzeiro & 376 & 2.501 & 6,7 & 11,1 & 1,67 & 0,624 & $\mathrm{C}$ e $\mathrm{R}$ \\
\hline Mogi das Cruzes & 214 & 900 & 4,2 & 5,0 & 1,19 & 0,464 & $\mathrm{C}$ e $\mathrm{R}$ \\
\hline Paraibuna e Natividade & 249 & 1.685 & 6,8 & 12,8 & 1,89 & 0,649 & $\mathrm{C}$ \\
\hline São José dos Campos & 244 & 1.110 & 4,6 & 6,8 & 1,49 & 0,570 & $\mathrm{C}$ \\
\hline São Luiz do Paraitinga & 383 & 2.079 & 5,4 & 9,7 & 1,78 & 0,611 & $\mathrm{C}$ \\
\hline São Sebastião a & 385 & 1.277 & 3,3 & 3,4 & 1,02 & 0,467 & $\mathrm{C}$ \\
\hline Taubaté & 663 & 4.164 & 6,3 & 11,6 & 1,85 & 0,638 & M \\
\hline
\end{tabular}

Obs: D. P. = desvio-padrão, C. V. = coeficiente de variação, $\mathrm{M}=$ Matrícula, C = Classificação e $\mathrm{R}=$ Relação. a Inclui Caraguatatuba e Ilha Bela. 


\section{BRAZILIAN CENSUS SOURCES AND OWNERSHIP OF SLAVES IN THE 1870 S}

There exists a significant group of sources of a census nature for the study of slavery in the 1870s. These sources derive mainly from the registration of slaves that was established by the Law of the Free Womb of 1871. In this article, we discuss the different ways of presenting registration information. We analyze a sample of the registered slave population, including 69 towns from different parts of the country that total a little over 112,000 slaves and 25, 000 slave holders. In addition to characterizing the demographic profile of the slaves that make up the sample, we verify the ownership of slaves.

KEY WORDS: Registration, slavery, demography, slave ownership, Law of the Free Womb.

\section{FUENTES CENSALES BRASILEÑAS Y PROPIEDAD DE ESCLAVOS EN LA DÉCADAD DE 1870}

Existe un conjunto expresivo de fuentes de carácter censal para el estudio de la esclavitud en la década de 1870 en Brasil. Estas fuentes derivan, principalmente, de la matrícula de los esclavos determinada por la Ley de Vientre Libre de 1871. En este artículo discutimos las diferentes formas de presentación de las informaciones de la matrícula. Analizamos una muestra de la población esclava matriculada, comprendiendo 69 localidades de diferentes partes del país que totalizan poco más de 112.000 esclavos y 25.000 esclavistas. Al caracterizar el perfil demográfico de los esclavos de nuestra muestra, comprobamos la propiedad de esclavos.

Palabras clave: Censo, esclavitud, demografía, propiedad esclava, Ley de Vientre Libre. 